\title{
Scabies in Resource-Poor Communities in Nasarawa State, Nigeria: Epidemiology, Clinical Features and Factors Associated with Infestation
}

\author{
Uade Samuel Ugbomoiko ${ }^{1, *(\mathbb{D})}$, Samuel Adeola Oyedeji ${ }^{1}$, Olarewaju Abdulkareem Babamale ${ }^{1}$ \\ and Jorg Heukelbach ${ }^{2,3}$ \\ 1 Parasitology Unit, Department of Zoology, University of Ilorin, PMB 1515 Ilorin, Nigeria; \\ oyedejisamed@gmail.com (S.A.O.); olas4nice2004@yahoo.co.uk (O.A.B.) \\ 2 Department of Community Health, School of Medicine, Federal University of Ceará, \\ Fortaleza CE 60430-140, Brazil; heukelbach@web.de \\ 3 College of Public Health, Medical and Veterinary Sciences, Division of Tropical Health and Medicine, \\ James Cook University, Townsville 4811, Australia \\ * Correspondence: samugbomoiko@yahoo.com; Tel.: +234-8033585881
}

Received: 24 April 2018; Accepted: 29 May 2018; Published: 4 June 2018

\begin{abstract}
Epidemiology and clinical features of scabies remain largely unknown in Nigeria's rural communities. To fill this gap, we performed a cross-sectional study in three rural communities in north central Nigeria. A total of 500 individuals were included and examined for scabies infestation; a questionnaire was applied to collect socio-demographic and behavioral data. Scabies was diagnosed in $325(65.0 \%)$ participants. Excoriations $(68.6 \%)$, vesicles $(61.8 \%)$, and papules $(58.8 \%)$ were common skin lesions. Itching was the most common symptom $(77.5 \%) ; 64 \%$ complained of sleep disturbances. Lymphadenopathy was identified in $48.3 \%$. Lesions were most commonly encountered on the abdomen (35.5\%), inguinal area (19.1\%), and interdigital spaces (14.2\%). Poverty-related variables, such as illiteracy (OR: 7.15; 95\% CI: 3.71-13.95), low household income (7.25; 1.19-88.59), absence of a solid floor inside house $(12.17 ; 2.83-52.34)$, and overcrowding $(1.98 ; 1.08-2.81)$ were significantly associated with infestation. Individual behavior, such as sharing of beds/pillows $(2.11 ; 1.42-3.14)$ and sharing of clothes $(2.51 ; 1.57-3.99)$, was also highly significantly associated with scabies. Regular bathing habits $(0.37 ; 0.24-0.56)$ and regular use of bathing soap $(0.36 ; 0.21-0.53)$ were protective factors. Scabies is extremely common in the communities under study and is associated with considerable morbidity. The disease is intrinsically linked with extreme poverty.
\end{abstract}

Keywords: scabies; epidemiology; parasitic skin disease; cross-sectional study; Nigeria

\section{Introduction}

Scabies is a common contagious parasitic skin disease and a public health problem, mainly in tropical and subtropical countries [1,2]. Hundreds of millions of people suffer from infestation in impoverished urban and rural communities worldwide [3-6]. Outbreaks of scabies in closed groups have been reported particularly from high income countries, but the disease is more common in resource-poor communities in low and middle income countries in tropical climate zones [7-9]. High prevalence and re-infestations in endemic settings are correlated with armed conflicts, homelessness, crowding, and communal use of clothes, beds, and pillows [10,11]. Between $18 \%$ and $70 \%$ of people are reported to be affected in resource-limited communities in India, on south Pacific islands, and in Australian Aboriginal communities [1,8,12], with severe morbidity being common, such as abscess formation, lymphadenopathy, and post-streptococcal glomerulonephritis [8,13-15]. 
Control and prevention strategies by chemotherapy require considerable public health services and home resources, since treatment is often cumbersome and stressful $[2,16]$.

The prevalence of scabies disease remains largely unknown in Nigeria, in the face of many other health problems considered of more severe morbidity [17-19]. Only a limited number of hospital-based studies have described scabies and other skin diseases [20-24]. However, the upsurge in communal clashes and terrorist insurgence have increased the number of refugees and infectious diseases in all cardinal zones of the country, which poses vulnerable communities at higher risk for scabies infestation. To provide information on the epidemiology of scabies in Nigeria, a cross-sectional community-based study of scabies infestation was conducted in impoverished rural communities in north central Nigeria.

\section{Materials and Methods}

\subsection{Study Area}

The study was conducted in three indigenous communities in the Lafia Local Government Area (LGA) of Nasarawa State (north central Nigeria). State health workers had communicated endemicity of scabies from these communities. The areas (latitude $8^{\circ} 32^{\prime} \mathrm{N}$; longitude $8^{\circ} 18^{\prime} \mathrm{E}$ ) are largely settlements with an estimated population of 3300 inhabitants (National Population Commission, 2007). The climate condition in the state is tropical with a mean daily temperature of $40{ }^{\circ} \mathrm{C}$ and relative humidity of $90 \%$ during the dry season (November-April).

In the area there have been several violent communal disturbances, with consequently many families being displaced and living under inappropriate housing conditions. Most houses are built with clay or palm products, and there is no electricity, nor a structured community waste disposal system. The inhabitants are predominantly Muslims. The people are largely illiterate subsistence farmers of food crops and cattle herders, with $84 \%$ of the households on a monthly per capital income of $<\mathrm{N} 18,000$ (equivalent to US $\$ 50$ at the time of study), the national minimum wage. Human and animal waste is littered around compounds and is widely dispersed during heavy rains. Rivers and streams serve as the major source of water supply. Roads are caliche-topped. Public schools and health centers in the areas are deplorable and poorly staffed. School-aged children (locally called 'Almagiri') are compelled to solicit for food and finance for their daily existence.

\subsection{Study Design}

For the purpose of this study, the three communities under study were considered as one study area. Prior to the study, a complete household census conducted in the study area identified 390 households (about 3300 individuals), which were listed and subsequently numbered. Using the Epi Info Software package (version 6.04d), we estimated that a population of 344 individuals was sufficient for the prevalence study with $80 \%$ power and $95 \%$ confidence level. Considering a safety margin (due to expected high non-participation) and a cluster effect (household sampling), a total of 209 households comprising 1050 individuals were selected using a random number generator (Epi Info version 6.04d, Centers for Disease Control and Prevention, Atlanta, GA, USA).

The study was conducted during the dry season (data collection November 2016-April 2017). All members in the selected households were eligible for the study except for individuals who declined participation and those who had not spent at least five days per week in the previous two months in the study area. Those who consented were registered and interviewed to obtain information on their biodata (name, sex, age, and educational background), socioeconomic information, and environmental and behavioral variables, using pre-tested structured questionnaires.

Thereafter, the entire skin surface including the genital areas of each participant was carefully examined clinically for scabies infestation. Children aged $<10$ years were examined in the presence of their parents or caregivers. In the absence of any household members, the houses were revisited three times. 


\subsection{Case Definition and Skin Examination}

Within the realm of this study, scabies was defined on the basis of a symptomatic description proposed and used by our group previously $[9,10,13]$-namely, presence of at least two of the following requirements: 1 . one or more typical lesions for longer than 2 weeks; 2 . pruritus that intensified at night; 3 . at least one more family member with similar lesions. Typical skin lesions included papules, vesicular rash, and nodules.

For description of topographical distribution of lesions and parts of the affected skin surfaces, the entire body surface was vertically divided into left and right sides. Each side was subdivided into interdigital spaces, hand, wrist, arm, elbow, axilla, leg, foot, abdomen, thorax, mamilla/perimammillar area, back, buttock, genital/inguinal area, and head (scalp/neck/face) [6]. Primary lesions were distinguished as macular, papules, crusted papules (if a tiny hemorrhage crusts), vesicles, and nodules [3,6,8,25]. Excoriations on skin and bacterial superinfection were noted when pustules, abscess, or suppuration were observed. Lymph nodes were palpated to confirm lymphadenopathy while the intensity of itching was assessed semi-quantitatively and graded as absent, light, moderate, and heavy, using visual ordinal scales. To guarantee privacy of participants, all individuals were examined in a well-lighted room provided in the households. Examinations were performed by one male investigator (SAO) extensively trained in diagnosis of scabies, and assisted by a female senior nursing officer of the Dermatology unit of Nasarawa Central Hospital.

\subsection{Statistical Analysis}

Data were double-entered into a database and crosschecked for entry errors, using SPSS version 16.0 for Windows (SPSS Inc., Chicago, IL, USA). Chi-squared statistics was applied to determine the significance of differences of relative frequencies between groups. Age groups were defined as follows: $\leq 10$ years, $11-15$ years, $16-20$ years, $\geq 21$ years. Bivariate analysis and multivariate logistic regression models were applied to identify independently associated variables measured on the prevalence of scabies in the communities. Variables were checked for collinearity before inclusion in the multivariate model.

\subsection{Ethical Considerations}

The study protocol for this study was approval by the Ethical Review Committee of the University of Ilorin, Nigeria and the Primary Health Care Unit of the Lafia Local Government Area of Nasarawa State. Prior to the study, informed consent was obtained from adult participants and from the parents or legal guardians of minors after detailed explanation of the study protocol. In accordance with the ethical review committee requirements, patient information was made confidential.

\section{Results}

\subsection{Characteristics of Study Population}

The target population consisted of 1050 individuals (546 males and 504 females) belonging to 144 households. Seventy-eight individuals failed inclusion criteria, and 38 moved to neighbouring communities during the study. Of the remaining 934 individuals, the data records of 65 were incomplete (interview data or clinical examination). A total of 369 females declined participation for religious and cultural reasons.

Consequently, the study population consisted of 500 individuals, comprising more males $(n=429)$ than females $(n=71)$. The age of individuals ranged from 1 to 34 years (median $=14$ years), and the household size ranged from 2 to 14 persons (median $=6$ ).

The characteristics of the study population are presented in Table 1. The study population was primarily illiterate, with an illiteracy rate of almost $90 \%$. Males and age group $>21$ years were disproportionately highly represented in the study population. 
Table 1. Characteristics of study population $(n=500)$.

\begin{tabular}{lc}
\hline Variable & N (\%) \\
\hline Sex & \\
Male & $429(85.8)$ \\
Female & $71(14.2)$ \\
\hline Age group (years) & \\
$\leq 10$ & $104(20.8)$ \\
$11-15$ & $232(46.4)$ \\
$16-20$ & $117(23.4)$ \\
$\geq 21$ & $47(9.4)$ \\
\hline Community & \\
Lafia Municipal & $175(35.0)$ \\
Lafia East & $160(32.0)$ \\
Lafia North & $165(33.0)$ \\
\hline Education & \\
Illiterate & $440(88.0)$ \\
Primary & $48(9.6)$ \\
Post primary & $12(2.4)$ \\
\hline Presence of scabies-typical lesions & \\
Yes & $325(65.0)$ \\
No & $175(35.0)$ \\
\hline Type of lesions & \\
Papules & $191(58.8)$ \\
Crusted papules & $105(32.3)$ \\
Vesicles & $201(61.8)$ \\
Macules & $160(49.2)$ \\
Pustules & $132(40.6)$ \\
Excoriations & $223(68.6)$ \\
\hline
\end{tabular}

\subsection{Scabies Prevalence and Clinical Features}

A total of 325 (65.0\%) participants were diagnosed with scabies. Excoriations, vesicles, and papules were the most common skin lesions (Table 1). There were no cases of crusted scabies. The prevalence of scabies stratified by socio-demographic and cultural factors is presented in Table 2. Age groups $<15$ years showed highest prevalences (accounting for $76.3 \%$ of all infected cases), and infestation was significantly more common in females (74.6\%) than in males (60.6\%).

Signs and symptoms associated with scabies are presented in Table 3. Itching was the most common symptom $(77.5 \%)$, with $56 \%$ presenting severe itching; $52 \%$ complained of itching-related sleep disturbance. Lymphadenopathy was identified in about half of the infected cases, commonly in the inguinal and cervical regions.

The topographic distribution of lesions is shown in Table 3. Lesions were most commonly encountered on the abdomen (35.4\%), inguinal area (19.1\%), and interdigital spaces (14.5\%).

\subsection{Factors Associated with Infestation}

Table 2 presents the bivariate analysis of factors associated with scabies infestation. Prevalence in $<16$-year-olds was significantly higher than in older age groups. Poverty-related variables such as illiteracy, low household income, inadequate housing, unemployment, and overcrowding were significantly associated with scabies. Sharing of beds/pillows and sharing of clothes were also highly significantly associated with infestation. Regular bathing habits and regular use of bathing soap were protective factors. In multivariate logistic regression analysis, poverty-related variables remained independent factors significantly associated with infestation (Table 4). 
Table 2. Prevalence of scabies and bivariate analysis of socio-demographic and behavioral factors associated with infestation.

\begin{tabular}{|c|c|c|c|c|}
\hline Variable & $n$ & $\%(95 \% \mathrm{CI})$ & OR $(95 \% \mathrm{CI})$ & $p$ Value \\
\hline \multicolumn{5}{|l|}{ Age group } \\
\hline$\leq 10$ & $63 / 104$ & $60.6(50.5-69.9)$ & $2.16(1.00-4.56)$ & 0.013 \\
\hline$\overline{11}-15$ & $185 / 232$ & $79.7(73.9-84.6)$ & $2.90(1.34-3.19)$ & 0.016 \\
\hline $16-20$ & $58 / 117$ & $49.6(40.3-59.0)$ & $1.97(0.17-2.28)$ & 0.585 \\
\hline$\geq 21$ & $19 / 47$ & $40.4(26.7-55.7)$ & Ref. & \\
\hline \multicolumn{5}{|l|}{ Sex } \\
\hline Male & $272 / 429$ & $63.4(58.6-67.9)$ & $0.52(0.04-0.72)$ & 0.015 \\
\hline Female & $53 / 71$ & $74.6(62.7-83.9)$ & Ref. & \\
\hline \multicolumn{5}{|l|}{ Illiteracy } \\
\hline Yes & $310 / 440$ & $70.5(65.9-74.6)$ & 7.15 (3.71-13.95) & $<0.001$ \\
\hline No & $15 / 60$ & $25.0(15.1-38.1)$ & Ref. & \\
\hline \multicolumn{5}{|l|}{ Occupation } \\
\hline Unemployed & $304 / 445$ & $68.3(63.7-72.6)$ & $3.83(1.65-8.89)$ & $<0.001$ \\
\hline Farming & $12 / 30$ & $40.0(23.2-59.2)$ & $1.19(0.40-3.55)$ & 0.764 \\
\hline Wage earner & $9 / 25$ & $36.0(18.7-57.4)$ & Ref. & \\
\hline \multicolumn{5}{|c|}{ Monthly income (NGN) } \\
\hline$\leq 18,000$ & $312 / 424$ & $73.6(69.1-77.7)$ & 7.25 (1.19-88.59) & 0.011 \\
\hline$>18,000$ & $13 / 76$ & $17.1(9.7-27.8)$ & Ref. & \\
\hline \multicolumn{5}{|c|}{ No. of persons/room/bed } \\
\hline$<4$ & $90 / 179$ & $50.3(42.8-57.8)$ & Ref. & \\
\hline$>4$ & $235 / 321$ & $73.2(67.9-79.9)$ & $1.98(1.08-2.81)$ & 0.004 \\
\hline \multicolumn{5}{|l|}{ House structure } \\
\hline Bricks & $100 / 168$ & $59.5(51.7-66.9)$ & Ref. & \\
\hline Adobe & $215 / 321$ & $66.9(61.5-72.0)$ & $1.15(0.18-1.28)$ & 0.071 \\
\hline Palm product & $10 / 11$ & $90.9(57.1-99.5)$ & $2.20(1.26-2.61)$ & 0.031 \\
\hline \multicolumn{5}{|l|}{ Type of floor } \\
\hline Sandy & $29 / 31$ & $93.5(79.2-98.9)$ & $12.17(2.83-52.34)$ & 0.001 \\
\hline Clay & $184 / 263$ & $70.0(63.9-75.4)$ & $1.96(1.34-2.86)$ & 0.001 \\
\hline Cemented & $112 / 283$ & $39.6(33.9-45.6)$ & Ref. & \\
\hline \multicolumn{5}{|c|}{ Shared beds and pillows } \\
\hline Yes & $247 / 352$ & $70.2(65.0-74.8)$ & $2.11(1.42-3.14)$ & $<0.001$ \\
\hline No & $78 / 148$ & $52.7(44.4-60.9)$ & Ref. & \\
\hline \multicolumn{5}{|l|}{ Sharing of clothes } \\
\hline Yes & $105 / 135$ & $77.8(69.7-84.3)$ & $2.51(1.57-3.99)$ & $<0.001$ \\
\hline No & $220 / 367$ & $59.9(54.7-64.9)$ & Ref. & \\
\hline \multicolumn{5}{|l|}{ Bathing habits } \\
\hline Regular & $193 / 333$ & $58.0(52.4-63.3)$ & $0.37(0.24-0.56)$ & $<0.001$ \\
\hline Irregular & $132 / 167$ & $79.0(72.3-84.5)$ & Ref. & \\
\hline \multicolumn{5}{|c|}{ Use of bathing soap } \\
\hline Regular & $204 / 350$ & $58.352 .9-63.5)$ & $0.36(0.21-0.53)$ & $<0.001$ \\
\hline Irregular & $121 / 150$ & $80.7(73.2-86.5)$ & Ref. & \\
\hline
\end{tabular}


Table 3. Clinical features and topographical location of scabies infestation $(n=325)$.

\begin{tabular}{lc}
\hline Variable & $\mathbf{N} \mathbf{( \% )}$ \\
\hline Itching & $252(77.5)$ \\
Light & $45(17.9)$ \\
Moderate & $65(25.8)$ \\
Severe & $142(56.3)$ \\
\hline Sleeping disturbance & $208(64.0)$ \\
Due to itching & $109(52.4)$ \\
Due to pain & $32(15.4)$ \\
Others & $67(32.2)$ \\
\hline Lymphadenopathy & $157(48.3)$ \\
Cervical & $35(22.3)$ \\
Axillar & $22(14.0)$ \\
Inguinal & $100(64.1)$ \\
\hline Infected skin & $222(68.3)$ \\
\hline Suppuration & $119(36.6)$ \\
\hline No complaints & $67(20.6)$ \\
\hline Topographical location of lesions & \\
Abdomen & $115(35.4)$ \\
Inguinal/thigh & $62(19.1)$ \\
Wrist & $41(12.6)$ \\
Interdigital & $46(14.5)$ \\
Legs & $23(7.1)$ \\
Elbow & $9(2.8)$ \\
Buttock & $27(8.3)$ \\
Arms & $12(3.7)$ \\
Hands & $45(13.8)$ \\
Thoet & $2(0.6)$ \\
\hline & $1(0.3)$ \\
\hline
\end{tabular}

Table 4. Multivariate analysis of factors independently associated with scabies.

\begin{tabular}{lccc}
\hline Variable & Adjusted Odd Ratio & $\mathbf{9 5 \%}$ CI & $p$ Value \\
\hline Household income $<1$ minimum wage & 3.23 & $1.94-3.85$ & 0.026 \\
Sharing of bed and pillow & 3.03 & $2.53-3.21$ & 0.015 \\
Female sex & 2.72 & $1.56-3.52$ & 0.062 \\
Poor housing conditions (no brick house) & 2.61 & $1.94-3.06$ & $<0.001$ \\
Unemployment & 2.23 & $1.15-2.59$ & 0.001 \\
Sharing of clothes & 2.11 & $1.88-2.53$ & 0.041 \\
Illiteracy & 1.67 & $1.01-1.93$ & 0.002 \\
Irregular bathing with soap & 1.96 & $0.97-2.13$ & 0.011 \\
Age $\geq 15$ years & 0.92 & $0.42-1.05$ & 0.062 \\
\hline
\end{tabular}

\section{Discussion}

Our study represents the first systematic community-based study on scabies conducted in Nigeria, revealing an extremely high prevalence and morbidity of scabies. The disease was associated with poverty-related variables even within the communities under study, which can be characterized as extremely resource-poor, with precarious living conditions. The high prevalence recorded in the present study indicates the under-recognition of the disease in resource-poor communities, and difficult access to the health system. The prevalence of $65 \%$ is comparable to studies in specific and high-risk populations worldwide. For example, prevalences were similar or even higher in a Bangladeshi Islamic religious school (61\%) [26], displacement camps in Sierra Leone 67\%) [27], Thailand orphanages (87\%) [28], a Korean leprosarium (87\%) [29], and in a rural village in Papua New Guinea (80\%) [30]. 
Other studies from Nigeria reported lower prevalences of 5\% to $57 \%$ [20-22]. Other African countries (Cameroon-18\% [31], Malawi-36\% [32]), as well as Cambodia (4.3\%) [33], Brazil (9-10\%) [9,10,34], and Fiji (24\%) [2] also reported lower prevalences, as compared to our study.

The endemicity of scabies and the associated burden have been attributed to a wide range of intervening factors previously, including socio-economic factors, overcrowding, and behavioral and environmental variables $[1,10,13,35]$. Consistent with these reports, our findings confirmed poor housing conditions and behavior such as sharing of beddings and pillows-which may serve as fomites-as important risk factors. Overcrowding in the study area was worsened by internal migration of refugees from neighboring communities due to recent communal clashes and terrorist insurgencies. In fact, crowding is a known risk factor for scabies, and has been reported previously in several studies from endemic areas in Egypt [36], Sierra Leone [27], Mali [33], Brazil [10], India [26], and Thailand [28]. Similarly, other proxies for poverty such as unemployment, low income, communal use of clothing, and illiteracy were significantly associated. Multivariate analysis indicated the importance of hygiene habits as independent protective factors.

Another major outcome of this study is the uneven distribution of scabies and its morbidity. Our data show that scabies in the female study population was significantly higher, as compared to males. However, considering the high non-participation rate in females, this figure must be taken with care. There was also a considerable variation in prevalence with age. Children of school age were more frequently infested than the older age groups. This is in agreement with other studies from endemic areas [9,37], indicative of the high frequency of interaction and poor hygiene that enhances transmission amongst these highly mobile age groups. In our study area, these age groups are mostly schoolchildren of private Islamic schools that are sent out by school owners to roam around the streets as so-called Almajiri (beggars) and beg for food and money (OAB, personal observation). The observed occurrence of scabies in the middle and older age groups $>21$ years may be attributed to sustained contact with infested children, especially in the female population.

We also observed that the topographical distribution of the morbidity-associated features of scabies varied in the population. More than $14 \%$ of the infested had more than one type of lesion in various topographic sites, commonly on the abdomen, inguinal/thigh, interdigital space, hands, and wrists, confirming previous reports [3,6,9]. In our study area, a climate-determined behavior in which people, particularly male children, expose greater parts of the body and maintain prolonged close physical contact facilitates transmission of scabies mite. This partly explained why lesions commonly occurred on the abdomen, hands, and wrists in this study.

Our data further show that the prevalence of both itching and excoriation in the affected population was high $(77.5 \%$ and $68.3 \%$, respectively). Scabies-related itching is a host allergic immune response to mite products [38]. Usually, in resource-limited settings, secondary bacterial infection is common due to poor hygiene conditions and overcrowding [39]. Intense itching and scratching result in skin breaks and facilitates secondary bacterial infection among the affected population $[9,13,32,37,40]$. Lymphadenopathy has also been well correlated to secondarily-infected scabies lesions in individuals $[9,34]$. In the current study, high proportions of lymphadenopathy and itching were reported in the affected population. Similar conditions are, however, not uncommon with other parasitic skin disease, such as tungiasis and cutaneous larva migrans [17,41]. Severe itching has also been reported to induce sleep disturbances in scabies-affected individuals. Although other diseases may induce sleep disturbance, the observation that sleep was more often disturbed at a time that coincides with the peak activities of the sarcoptic mites indicates the involvement of this mite. Sixty-four percent of the population with scabies reported sleep disturbance. This is comparable to $77 \%$ of cases reported previously from Brazilian communities [6].

Scabies is increasingly recognised as a common parasitic skin disease in Nigerian children [20-22], particularly in poor rural communities where important infrastructural facilities including health care services are unavailable or inadequate. With the current socioeconomic and lifestyle patterns of people 
where living conditions are precarious—e.g., families sharing clothing and bed space—scabies will be continuously endemic, with high prevalences.

The cost of and access to healthcare services is prohibitive and difficult for many individuals at risk living in the study area and elsewhere in Nigeria in similar settings. Thus, traditional medication, which often complicates disease conditions, is an alternative choice of care by many affected people. Alleviating the scourge of potentially preventable and treatable diseases such as scabies is fundamental in public health service. In Nigeria, and indeed many other African countries, identification and treatment of cases appears to be the only management option in the face of paucity of reliable epidemiological data for control programs. The effectiveness of oral ivermectin in the treatment of scabies and other parasitic diseases such as pediculosis, lymphatic filariasis, onchocerciasis, and intestinal helminthiasis has been widely reported from endemic areas in Africa, South America, and Pacific Islands $[1,3,8,13,39]$. In endemic communities, control programs by oral ivermectin chemotherapy could be integrated into other existing parasite control programs with strong advocacy on health education, training of health personnel, and surveillance.

Our study is subject to several limitations, and internal and external validity of data may have suffered from the extremely difficult field conditions under which this study took place. Given the considerable difference in participation rates between males and females, and under-representation of adults, prevalence data may have suffered from participation bias. Many female non-participants declined due to cultural and religious beliefs. During field work in the community, we sought to discern other reasons for the striking gender-driven non-participation, but could confirm repeatedly during interviews with community members that the major reasons for non-participation in females in fact were of socio-cultural origin, and not related to symptomatic scabies infestation status (SAO, personal communication). Diagnosis of scabies was based on clinical features; microscopic examination of skin scrapings, videodermatoscopy, and bacteriological testing to validate the presence of mite and bacterial infection in lesions, could not be conducted in this extremely difficult field setting. In some cases diagnosis may have been inaccurate; for example, untreated onchodermatitis (due to onchocerciasis) may have been misclassified as scabies. We aimed to reduce possible diagnostic error by systematic training and supervision of field investigators, and by meticulously adapting to the diagnostic approach as proposed by Heukelbach \& Feldmeier [13]. Despite the limitations mentioned, we believe that this population-based study from typical impoverished communities in Nigeria may reflect the situation in similar communities throughout the country.

\section{Conclusions}

Scabies is extremely common in the rural Nigerian communities under study, and associated with considerable morbidity. We have confirmed that even in the least developed and precarious communities, poverty-related variables are important risk factors for infestation and that hygiene habits may still have a protective effect, even in settings with extremely high transmission pressure. Communal clashes and disturbances related to displacement, overcrowding, and unemployment may further increase prevalence and scabies-related morbidity. Given the risk of sequelae related to chronic infestation and bacterial superinfection, an urgent response from the health care sector is mandatory. Intervention measures may be integrated into existing helminth control programs based on oral ivermectin mass treatment.

Author Contributions: U.S.U. and J.H. conceived and designed the experiments; S.A.O. performed data collection; O.A.B., U.S.U. and J.H. analyzed the data and interpreted results; U.S.U. and J.H. wrote the paper. All authors contributed substantially to the work reported.

Acknowledgments: The study was performed without any sources of funding. The authors wish to thank the communities for participation. This paper is dedicated to the memory of Rick Speare. J.H. is a class 1 research fellow at the Brazilian National Council for Scientific Development (CNPq).

Conflicts of Interest: The authors declare no conflict of interest. There were no funding sponsors. 


\section{References}

1. Hay, R.; Steer, A.; Engelman, D.; Walton, S. Scabies in the developing world-Its prevalence, complications, and management. Clin. Microbiol. Infect. 2012, 18, 313-323. [CrossRef] [PubMed]

2. Romani, L.; Koroivueta, J.; Steer, A.C.; Kama, M.; Kaldor, J.M.; Wand, H.; Hamid, M.; Whitfeld, M.J. Scabies and impetigo prevalence and risk factors in Fiji: A national survey. PLoS Negl. Trop. Dis. 2015, 9, e0003452. [CrossRef] [PubMed]

3. Chosidow, O. Scabies. N. Engl. J. Med. 2006, 354, 1718-1727. [CrossRef] [PubMed]

4. Murray, C.J.; Vos, T.; Lozano, R.; Naghavi, M.; Flaxman, A.D.; Michaud, C.; Ezzati, M.; Shibuya, K.; Salomon, J.A.; Abdalla, S. Disability-adjusted life years (DALYs) for 291 diseases and injuries in 21 regions, 1990-2010: A systematic analysis for the Global Burden of Disease Study 2010. Lancet 2012, 380, 2197-2223. [CrossRef]

5. Karimkhani, C.; Colombara, D.V.; Drucker, A.M.; Norton, S.A.; Hay, R.; Engelman, D.; Steer, A.; Whitfeld, M.; Naghavi, M.; Dellavalle, R.P. The global burden of scabies: A cross-sectional analysis from the Global Burden of Disease Study 2015. Lancet Infect. Dis. 2017, 17, 1247-1254. [CrossRef]

6. Jackson, A.; Heukelbach, J.; Júnior, C.; de Barros, E.; Feldmeier, H. Clinical features and associated morbidity of scabies in a rural community in Alagoas, Brazil. Trop. Med. Int. Health 2007, 12, 493-502. [CrossRef] [PubMed]

7. Andersen, B.; Haugen, H.; Rasch, M.; Haugen, A.H.; Tageson, A. Outbreak of scabies in Norwegian nursing homes and home care patients: Control and prevention. J. Hosp. Infect. 2000, 45, 160-164. [CrossRef] [PubMed]

8. Heukelbach, J.; Mazigo, H.D.; Ugbomoiko, U.S. Impact of scabies in resource-poor communities. Curr. Opin. Infect. Dis. 2013, 26, 127-132. [CrossRef] [PubMed]

9. Heukelbach, J.; Wilcke, T.; Winter, B.; Feldmeier, H. Epidemiology and morbidity of scabies and pediculosis capitis in resource-poor communities in Brazil. Br. J. Dermatol. 2005, 153, 150-156. [CrossRef] [PubMed]

10. Feldmeier, H.; Jackson, A.; Ariza, L.; Calheiros, C.M.L.; de Lima Soares, V.; Oliveira, F.A.; Hengge, U.R.; Heukelbach, J. The epidemiology of scabies in an impoverished community in rural Brazil: Presence and severity of disease are associated with poor living conditions and illiteracy. J. Am. Acad. Dermatol. 2009, 60, 436-443. [CrossRef] [PubMed]

11. Wang, C.-H.; Lee, S.-C.; Huang, S.-S.; Kao, Y.-C.; See, L.-C.; Yang, S.-H. Risk factors for scabies in Taiwan. J. Microbiol. Immunol. Infect. 2012, 45, 276-280. [CrossRef] [PubMed]

12. Fuller, L.C. Epidemiology of scabies. Curr. Opin. Infect. Dis. 2013, 26, 123-126. [CrossRef] [PubMed]

13. Heukelbach, J.; Feldmeier, H. Scabies. Lancet 2006, 367, 1767-1774. [CrossRef]

14. Engelman, D.; Kiang, K.; Chosidow, O.; McCarthy, J.; Fuller, C.; Lammie, P.; Hay, R.; Steer, A.; on behalf of the members of the International Alliance for the Control of Scabies (IACS). Toward the global control of human scabies: Introducing the International Alliance for the Control of Scabies. PLoS Negl. Trop. Dis. 2013, 7, e2167. [CrossRef] [PubMed]

15. Hengge, U.R.; Currie, B.J.; Jäger, G.; Lupi, O.; Schwartz, R.A. Scabies: A ubiquitous neglected skin disease. Lancet Infect. Dis. 2006, 6, 769-779. [CrossRef]

16. Yeoh, D.K.; Anderson, A.; Cleland, G.; Bowen, A.C. Are scabies and impetigo 'normalised'? A cross-sectional comparative study of hospitalised children in northern Australia assessing clinical recognition and treatment of skin infections. PLoS Negl. Trop. Dis. 2017, 11, e0005726. [CrossRef] [PubMed]

17. Ugbomoiko, U.S.; Ofoezie, I.E.; Heukelbach, J. Tungiasis: High prevalence, parasite load, and morbidity in a rural community in Lagos State, Nigeria. Int. J. Dermatol. 2007, 46, 475-481. [CrossRef] [PubMed]

18. McLean, F.E. The elimination of scabies: A task for our generation. Int. J. Dermatol. 2013, 52, 1215-1223. [CrossRef] [PubMed]

19. Feldmeier, H.; Heukelbach, J.; Ugbomoiko, U.S.; Sentongo, E.; Mbabazi, P.; von Samson-Himmelstjerna, G.; Krantz, I. Tungiasis-A neglected disease with many challenges for global public health. PLoS Negl. Trop. Dis. 2014, 8, e3133. [CrossRef] [PubMed]

20. Nnoruka, E. Skin diseases in south-east Nigeria: A current perspective. Int. J. Dermatol. 2005, 44, 29-33. [CrossRef] [PubMed]

21. Onayemi, O.; Isezuo, S.A.; Njoku, C.H. Prevalence of different skin conditions in an outpatients' setting in north-western Nigeria. Int. J. Dermatol. 2005, 44, 7-11. [CrossRef] [PubMed] 
22. Yahya, H. Change in pattern of skin disease in Kaduna, north-central Nigeria. Int. J. Dermatol. 2007, 46, $936-943$. [CrossRef] [PubMed]

23. Okafor, O.; Akinbami, F.; Orimadegun, A.; Okafor, C.; Ogunbiyi, A. Prevalence of dermatological lesions in hospitalized children at the University College Hospital, Ibadan, Nigeria. Niger. J. Clin. Pract. 2011, 14, 287-292. [CrossRef] [PubMed]

24. Ukonu, B.; Eze, E. Pattern of skin diseases at university of Benin teaching hospital, Benin city, Edo State, South-South Nigeria: A 12 month prospective study. Glob. J. Health Sci. 2012, 4, 148. [CrossRef] [PubMed]

25. McCarthy, J.; Kemp, D.; Walton, S.; Currie, B. Scabies: More than just an irritation. Postgrad. Med. J. 2004, 80, 382-387. [CrossRef] [PubMed]

26. Oztiirkcan, S.; Ozcelik, S.; Saygi, G.; Ozcelik, S. Spread of scabies and pediculus humanus among the children at Sivas orphanage. Indian Pediatr. 1994, 31, 210-213.

27. Terry, B.; Kanjah, F.; Sahr, F.; Kortequee, S.; Dukulay, I.; Gbakima, A. Sarcoptes scabiei infestation among children in a displacement camp in Sierra Leone. Public Health 2001, 115, 208-211. [CrossRef]

28. Pruksachatkunakorn, C.; Wongthanee, A.; Kasiwat, V. Scabies in Thai orphanages. Pediatr. Int. 2003, 45, 719-723. [CrossRef]

29. Park, H.; Lee, C.; Park, S.; Kwon, H.; Kweon, S.-S. Scabies among elderly Korean patients with histories of leprosy. Am. J. Trop. Med. Hyg. 2016, 95, 75-76. [CrossRef] [PubMed]

30. Bockarie, M.; Alexander, N.; Kazura, J.; Bockarie, F.; Griffin, L.; Alpers, M. Treatment with ivermectin reduces the high prevalence of scabies in a village in Papua New Guinea. Acta Trop. 2000, 75, 127-130. [CrossRef]

31. Kouotou, E.A.; Nansseu, J.R.N.; Kouawa, M.K.; Bissek, A.-C.Z.-K. Prevalence and drivers of human scabies among children and adolescents living and studying in Cameroonian boarding schools. Parasites Vectors 2016, 9, 400. [CrossRef] [PubMed]

32. Kristensen, J.K. Scabies and pyoderma in Lilongwe, Malawi. Int. J. Dermatol. 1991, 30, 699-702. [CrossRef] [PubMed]

33. Landwehr, D.; Keita, S.M.; Pönnighaus, J.M.; Tounkara, C. Epidemiologic aspects of scabies in Mali, Malawi, and Cambodia. Int. J. Dermatol. 1998, 37, 588-590. [CrossRef] [PubMed]

34. Jackson, A.; Heukelbach, J.; Feldmeier, H. Transmission of scabies in a rural community. Braz. J. Infect. Dis. 2007, 11, 386-387. [CrossRef] [PubMed]

35. Feldmeier, H.; Heukelbach, J. Epidermal parasitic skin diseases: A neglected category of poverty-associated plagues. Bull. World Health Organ. 2009, 87, 152-159. [CrossRef] [PubMed]

36. Hegab, D.S.; Kato, A.M.; Kabbash, I.A.; Dabish, G.M. Scabies among primary schoolchildren in Egypt: Sociomedical environmental study in Kafr El-Sheikh administrative area. Clin. Cosmet. Investig. Dermatol. 2015, 8, 105. [CrossRef] [PubMed]

37. Steer, A.C.; Jenney, A.W.; Kado, J.; Batzloff, M.R.; La Vincente, S.; Waqatakirewa, L.; Mulholland, E.K.; Carapetis, J.R. High burden of impetigo and scabies in a tropical country. PLoS Negl. Trop. Dis. 2009, 3, e467. [CrossRef] [PubMed]

38. Worth, C.; Heukelbach, J.; Fengler, G.; Walter, B.; Liesenfeld, O.; Hengge, U.; Feldmeier, H. Acute morbidity associated with scabies and other ectoparasitoses rapidly improves after treatment with ivermectin. Pediatr. Dermatol. 2012, 29, 430-436. [CrossRef] [PubMed]

39. World Health Organization; Department of Child, Adolescent Health, WHO; UNICEF. Handbook IMCI: Integrated Management of Childhood Illness; WHO: Geneva, Switzerland, 2005.

40. Feldmeier, H.; Singh Chhatwal, G.; Guerra, H. Pyoderma, group A streptococci and parasitic skin diseases-A dangerous relationship. Trop. Med. Int. Health 2005, 10, 713-716. [CrossRef] [PubMed]

41. Heukelbach, J.; Wilcke, T.; Meier, A.; Moura, R.C.S.; Feldmeier, H. A longitudinal study on cutaneous larva migrans in an impoverished Brazilian township. Travel Med. Infect. Dis. 2003, 1, 213-218. [CrossRef] [PubMed]

(C) 2018 by the authors. Licensee MDPI, Basel, Switzerland. This article is an open access article distributed under the terms and conditions of the Creative Commons Attribution (CC BY) license (http:/ / creativecommons.org/licenses/by/4.0/). 